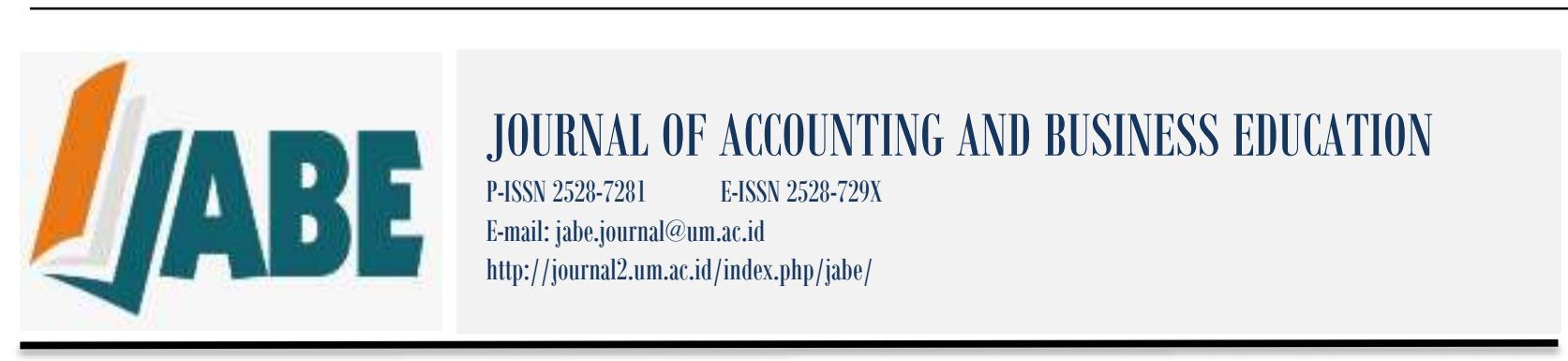

\title{
Does Emotional Intelligence and Religiosity Affect the Ethical Judgment of Accounting Students?
}

\author{
Sulastri ${ }^{1}$ \\ Ika Uswatun Kasanah ${ }^{2}$ \\ ${ }^{1,2}$ Accounting Department, Faculty of Economics, Universitas Negeri Malang, Indonesia \\ email: sulastri.fe@um.ac.id
}

\begin{abstract}
This study aims to determine the effect of Emotional Intelligence and religiosity on the ethical judgment of accounting students. The sample in this study amounted to 210 accounting student respondents. The sample in this study was taken by the purposive sampling technique. The data in this study were collected using a questionnaire and then analyzed using descriptive statistical analysis and multiple linear regression. Based on the research results, it is known that Emotional Intelligence and religiosity have a significant positive effect on the ethical judgment in accounting students. This means that the higher the level of Emotional Intelligence and the level of religiosity of students, the more assertive they will be in making an ethical judgment. Thus, based on the results of this study, it is hoped that educational institutions, especially at the university level, will provide services and training to accounting students to improve their Emotional Intelligence and religiosity. Also, companies can add indicators of Emotional Intelligence and religiosity in recruiting accounting staff and corporate auditors, to increase the company's credibility and integrity in the future.
\end{abstract}

Citation: Sulastri, S.,\& Kasanah, I.U. (2021). Does Emotional Intelligence and Religiosity Affect the Ethical Judment of Accounting Students?. Journal of Accounting and Business Education, 5(2), 21-30

\section{INTRODUCTION}

In recent years, several cases of ethical misconduct committed by accountants have been reported publicly. Accountants are responsible for safeguarding the public interest and ensuring good financial management of both the public and the private sectors to contribute to the nation's economy (Ismail \& Rasheed, 2019). If an accountant fails to apply good ethical standards in the workplace, it will hinder the commitment of the profession to serve the public interest (Keller et al., 2007). Several cases of accounting scandals occur because accountants do not make ethical judgments and ultimately lead to actions that violate the principles of the accountant's code of ethics.

Cases of violations of the professional ethics of accountants have occurred both abroad and domestically. One of them is carried out by the multinational British Telecom company. In 2017 British Telecom Italia was proven to have manipulated the value of company profits by falsifying contract renewals and invoices, and creating fake transactions with suppliers (Reuters, 2019). British Telecom's 
auditor, PwC (Pricewaterhouse Coopers), was also investigated for this scandal for alleged fraud in their audit (Economica, 2019).

The occurrence of these ethical violation cases has created a crisis of trust in the accounting profession and tarnished the reputation of accountants in the eyes of the public. It also provides evidence of the important role of ethics in the accounting profession. The ethical standards of accounting students currently enrolled in tertiary institutions reflect the ethics of the accounting profession in the future (Ismail \& Rasheed, 2019). Higher education is not only responsible for producing competent and insightful future accountants, but also must have good ethical standards and social responsibility. The importance of understanding the factors that shape the ethical standards of future accountants will help educational institutions develop appropriate ethics curricula for students and help companies develop appropriate ethics training for their employees (Keller et al., 2007).

Various ethical problems have occurred in the scope of students such as cases of academic fraud including cheating during exams, copying answers belonging to friends, plagiarism, leaving signatures for attendance, and many things that include the criteria for academic fraud (Sagoro, 2013). Students commit various acts of academic cheating because of the desire to get high scores. Even though there are still many ways that can be done to get high scores such as always attending every meeting, being active in class, collecting assignments on time, and studying hard. However, these students did not make ethical judgments so that they ended up committing unethical acts, namely academic fraud. Ethical judgment is important in influencing individual ethical decision-making processes when dealing with various ethical dilemmas including during the learning process at the college level. If the individual loses his view of ethical values, it can result in unethical actions like the case above.

Accounting students will then become accountants who occupy various strategic positions in the financial sector, both in government and private (Sagoro, 2013). As an accountant, in carrying out its role, you will be faced with various ethical dilemmas whose alternative solutions are conflicting. In situations like this, an accountant needs ethical judgment to make a decision. Accounting students as the next generation of the accounting profession ultimately also need to make an ethical judgment as a basis for ethical decision-making in facing various ethical dilemmas in the future.

Individual ethical judgment is influenced by many factors including the level of Emotional Intelligence. A manager who has a higher level of Emotional Intelligence believes that action must not deceive or harm others, in contrast to a manager with a lower level of Emotional Intelligence who tends to be willing to take action with negative consequences (Angelidis \& Ibrahim, 2011). Emotional Intelligence also significantly affects individual ethical behavior (Deshpande \& Joseph, 2009; Mesmer-Magnus et al., 2008).

The AICPA (American Institute of Certified Public Accountants) and the Institute of Management Accountants also state that Emotional Intelligence is an important factor influencing the success of an accountant (Akers \& Porter, 2003). Emotional Intelligence has a positive relationship with ethical judgment, someone who can understand the emotional state of those around him can direct his ethical judgment towards a more ethical one (Ismail \& Rasheed, 2019). Emotional Intelligence has a strong impact on auditors' ethical judgment (Ismail, 2015) and accounting students (Ismail \& Rasheed, 2019).

Another factor that influences ethical judgment is religiosity (Walker et al., 2012). As we know, Indonesia is known as a country where the majority of the population believes in God. This is also reflected in the 1st principle of Pancasila, which reads God Almighty. Most Indonesian people make God's decree as a source of law. Thus, religiosity can influence individual ethical decisions because there are rules that serve as guidelines in judging something right or wrong. Individuals who hold strong religious values will be more ethical in making ethical judgments (Resty, 2018), but different from Helmy (2018) who stated that religiosity does not affect ethical judgment.

It is known that in previous research, several differences in research results have been found. This becomes one of the reasons for the need to re-examine the factors that influence ethical judgment. This study not only focuses on discussing the effect of Emotional Intelligence on ethical judgment but also examines ethical judgment in terms of religiosity in accounting students. An accounting student is a prospective accountant who ultimately needs ethical judgment as a basis for ethical decision-making in 
facing various ethical dilemmas in the future. Research on the ethical judgment in accounting students is considered important to provide an overview of accountants' ethical decisions in the future.

\section{LITERATURE REVIEW AND HYPOTHESES}

\section{Theory of Moral Development}

Kohlberg (1984) argued that individual moral development is influenced by the process of thinking and arguing. There are three levels of moral development according to Kohlberg in (Nurhayati, 2006) namely pre-conventional, conventional, and post-conventional, which at each level consists of two stages as follows.

At the first level, namely the conventional level, individual morality is oriented towards physical impacts rather than psychological impacts and is oriented towards a sense of submission. Individual ethical behavior is based on external controls, on things that are commanded and prohibited. The preconventional level is the level for the majority of children under 10 years of age (Nurhayati, 2006). At the pre-conventional level, it consists of two stages, namely the orientation stage of obedience and fear of punishment and the stage of the orientation of naive egoistic/instrumental hedonism.

Furthermore, at the conventional level, an action is considered good if it meets the expectations of others. At this level, individuals behave not only to fulfill certain expectations or social order but also to appear loyal and want to identify themselves from a community group. Individuals also try to actively build good relationships between themselves and the people around them. The conventional level is the level for the majority of adolescents and adults (Nurhayati, 2006). There are two stages at the conventional level, namely the stage of good children's orientation and the stage of orientation to the morality of authority and social rules.

At the third or final level, namely the post-conventional level, moral value is defined as independent from a group, regardless of whether the individual is a member of a group or not. Individuals strive to obtain moral values that are more certain and have been recognized by the wider community and are universally applicable. The post-conventional level is the level achieved by several adults over the age of 24 years (Nurhayati, 2006). At the post-conventional level, it is divided into two stages, namely the morality orientation stage of the social contract and individual rights and the moral orientation of the principles that apply universally.

The theory of cognitive moral development states that every individual experiences various moral stages which are defined as a series of stages of cognitive moral development (Kohlberg, 1969). Individuals who pass through the stages of moral development will be able to make ethical considerations, while individuals who fail to go through the stages of moral development will be less or even unable to make ethical considerations (Aziz \& Cahyonowati, 2015). This means that individuals with higher levels of moral development will be more assertive in making ethical judgments.

\section{Ethical Judgment}

Ethical judgment is the process by which a person has acknowledged ethical issues and considered and determined which alternative is the most ethical to solve the problem (Hunt \& Vitell, 1986). Ethical judgment leads to making judgments about what actions should be done ethically right and right (Helmy, 2018). This means that ethical judgment is a process of determining which action is the most ethical in facing an ethical dilemma.

Rest in 1983 proposed a four-component framework for examining the development of individual moral thought processes and behaviors, namely ethical sensitivity, ethical considerations, ethical motivation, and ethical character (Chan \& Leung, 2006). The four components describe ethical decisionmaking and individual behavior through various processes, one of which is ethical considerations (Suliani \& Marsono, 2010). If an individual fails in making ethical judgment then it will also affect the individual's ethical actions and behavior. 


\section{Emotional Intelligence}

Emotional Intelligence is defined as a part of social intelligence that involves the ability to monitor the feelings and emotions of a person and others, and use this information to direct their thoughts and actions (Salovey \& Mayer, 1990). According to Salovey \& Mayer (1990), Emotional Intelligence has four different dimensions viz, Self Emotional Appraisal (SEA), Others Emotional Appraisal (OEA), Regulation of Emotion (ROE), and Use of Emotion (UOE).

The Self Emotional Appraisal (SEA) or self-assessment of emotions related to the ability of individuals to understand the emotions that exist within them and be able to express these emotions naturally (Wong \& Law, 2002). Someone who can feel their emotions more quickly and accurately tends to be better at expressing those emotions to others.

Furthermore, Others Emotional Appraisal (OEA) is an assessment and recognition of the emotions of others about an individual's ability to understand the emotions of those around him (Wong \& Law, 2002). A person who has high OEA abilities will be more sensitive to the feelings of others.

The Regulation of Emotion (ROE) is related to the regulation of emotions in themselves and the ability of individuals to control their emotions, which allows them to avoid prolonged psychological stresses (Wong \& Law, 2002). The Use of Emotion (UOE) is the management of emotions in performance related to how an individual manages their emotions and uses them for positive activities (Wong \& Law, 2002).

\section{Religiosity}

Glock \& Stark (1965) in (Pamungkas, 2014) defines religiosity as an integrated system of beliefs, lifestyles, ritual activities, and institutions that give meaning to human life and direct humans to sacred values or the highest values. Glock \& Stark in (Nasikhah \& Prihastuti, 2013) divides religiosity into five dimensions. The first dimension is the dimension of faith (The Ideological Dimension) which refers to an individual's belief in the teachings of his religion. This dimension considers what is considered true by individuals such as belief in the existence of gods, angels, and holy books.

The next is the dimensions of worship (The Ritualistic Dimension) that describes the extent to which an individual carries out his or her religious orders about religious practices. These religious practices can be religious practices in person or in general. The third dimension of appreciation (The Experiential Dimension) consists of an individual's appreciation of religious teachings such as how they feel about God and how their attitudes towards religion.

Then the fourth is the dimension of religious knowledge (The Intellectual Dimension) which describes the extent to which individuals understand the knowledge and teachings of their religion. The last dimension of the effect (The Consequential Dimension) measures how individuals can apply their religious teachings so that they can direct behavior in their social life. This dimension refers to the decisions and commitments of individuals in a society based on their beliefs, rituals, knowledge, and religious appreciation.

\section{The Effect of Emotional Intelligence on Ethical Judgment}

Emotional Intelligence refers to an individual's ability to understand the emotional state around him. Individuals who can control and manage these emotions well can direct their attitudes and place themselves in various situations. Emotional Intelligence can lead individuals to separate the various emotions that are used as material for thought in acting (Dewi et al., 2019). An individual who can understand the emotional state of himself and those around him can direct ethical judgment towards a more ethical (Ismail \& Rasheed, 2019).

Emotional Intelligence has a strong impact on a manager's (Angelidis \& Ibrahim, 2011), auditor's (Ismail, 2015), and accounting students' (Ismail \& Rasheed, 2019) ethical judgment. A manager who has a higher level of Emotional Intelligence will believe that an action should not be detrimental to others, on the other hand, a manager with a lower Emotional Intelligence level tends to be willing to take action with negative consequences (Angelidis \& Ibrahim, 2011). This means that the higher the level of an 
individual's Emotional Intelligence, the tighter he will be in making ethical judgments. Based on the explanation above, the following research hypothesis is formulated.

$\mathrm{H}_{1}$ : Emotional Intelligence has a positive effect on ethical judgment.

\section{The Effect of Religiosity on Ethical Judgment}

Religiosity is closely related to individual belief in God. The principles and commands of God that are believed by individuals provide an overview of how individuals should respond to and respond to what is happening around them. This in turn will also affect individual judgment in making a decision. Individuals who have a strong religion will always apply and consider God's teachings and commands in every decision and action they take.

Jaafar et al., (2004) argued that there is a real difference in terms of moral judgment between groups of Malay and American adolescents, Malay adolescents show a slightly higher level of moral reasoning than American adolescents. Malay adolescents reflect Malay religious principles and cultural values in moral considerations when compared to American adolescents who reflect personal responsibility, freedom, self-interest as justification for moral reasons (Jaafar et al., 2004). Walker et al., (2012) in their research stated that religiosity affects individuals in doing ethical judgment. These results are in line with research conducted on students in Minangkabau that the level of religiosity has a positive effect on their ethical judgment (Resty, 2018). Based on the explanation above, the following research hypothesis is formulated.

$\mathrm{H}_{2}$ : Religiosity has a positive effect on ethical judgment.

\section{METHODS}

This research is an explanatory study that aims to explain the relationship between emotional intelligence and religiosity on the ethical judgment. Using the purposive sampling technique, a sample was taken with the criteria for accounting students who have taken courses in business and professional ethics. These students were chosen because they were considered to have basic knowledge of professional ethics so that they could identify and determine ethical and unethical behavior. The number of samples used in this study was 210 respondents.

Emotional Intelligence is an individual's sensitivity to the feelings or emotions of himself and others, which then controls and manages the information to direct his thoughts and actions. This variable is measured by a questionnaire which includes four dimensions of Emotional Intelligence, namely selfemotional appraisal (SEA), others emotional appraisal (OEA), regulation of emotion (ROE), and use of emotion (UOE) which are adopted from Wong \& Law (2002). Respondents were asked to respond to the form of a four-point Likert scale with an answer preference level, namely strongly disagree, disagree, agree, and strongly agree.

Religiosity is an individual's belief in God, applying and considering God's principles and provisions in every decision or action. The religiosity variable is measured by a questionnaire which includes five dimensions of religiosity, namely the dimension of belief, the dimension of worship, the dimension of appreciation, the dimension of religious knowledge, and the effect dimension adopted from Fadhilah (2019) and Rahmawati (2019). Respondents were asked to respond to the form of a four-point Likert scale with an answer preference level, namely strongly disagree, disagree, agree, and strongly agree.

Ethical judgment is a process of considering and determining which action is the most ethical in dealing with an ethical dilemma. In this study, the variable ethical judgment was measured by presenting six illustrations of ethical dilemmas adopted from Emerson et al., (2007). Respondents were asked to respond to the form of a four-point Likert scale with an answer preference level, namely strongly disagree, disagree, agree, and strongly agree. The data collection technique in this study was through distributing questionnaires. The closed questionnaire was used in this study. The data collected were analyzed using descriptive statistical analysis and multiple linear regressions. 


\section{RESULTS AND DISCUSSION}

\section{Description of Respondents}

Based on the data collected, it is known that most of the respondents in this study were female. As can be seen in Table 1, female respondents in this study were 166 people or $79 \%$, while male respondents were 44 people or $21 \%$.

Table 1. General Description of Respondents by Gender

\begin{tabular}{ccc}
\hline Gender & Number of Respondents & Percent \\
\hline Females & 166 & $79 \%$ \\
Males & 44 & $21 \%$ \\
Total & 210 & $100 \%$ \\
\hline
\end{tabular}

\section{Multiple Linear Regression Test}

The $\mathrm{F}$ test in this study was used to see the effect of the independent variable Emotional Intelligence (X1) and religiosity (X2) on the dependent variable ethical judgment (Y) simultaneously.

Table 2. F-test Results

\begin{tabular}{clrrrrr}
\hline Model & & Sum of Squares & Df & Mean Square & F & Sig \\
\hline \multirow{2}{*}{1} & Regression & 200.723 & 2 & 100.362 & 17.117 & $.000^{\mathrm{b}}$ \\
& Residual & 1213.701 & 207 & 5.863 & & \\
& Total & 1414.424 & 209 & & & \\
\hline
\end{tabular}

Based on table 2, it can be seen that the significant value is $0.000<0.05$. It can be concluded that the Emotional Intelligence (X1) and religiosity (X2) variables simultaneously influence ethical judgment (Y). Furthermore, to determine the effect of each independent variable Emotional Intelligence and religiosity on the dependent variable ethical judgment was carried out using the t-test.

Table 3. Results of $t$-Test

\begin{tabular}{|c|c|c|c|c|c|c|}
\hline \multirow{2}{*}{\multicolumn{2}{|c|}{ Model }} & \multicolumn{2}{|c|}{$\begin{array}{c}\text { Unstandardized } \\
\text { Coefficients }\end{array}$} & \multirow{2}{*}{$\begin{array}{c}\text { Standardized } \\
\text { Coefficients } \\
\text { Beta } \\
\end{array}$} & \multirow[t]{2}{*}{$\mathrm{T}$} & \multirow[t]{2}{*}{ Sig. } \\
\hline & & B & Std. Error & & & \\
\hline \multirow[t]{3}{*}{1} & (Constants) & 11.070 & 1.554 & & 7.121 & .000 \\
\hline & Emotional Inteligence (X1) & .146 & .047 & .211 & 3.093 & .002 \\
\hline & Religiosity (X2) & .263 & .071 & .251 & 3.689 & .000 \\
\hline
\end{tabular}

Based on Table 3, it is known that the significance value is $0.000<0.05$ with a beta coefficient value of 0.211 . This means that Emotional Intelligence has a significant positive effect on the ethical judgment. So it can be concluded that $\mathrm{H} 1$ is accepted. Furthermore, the significance value for the religiosity variable is $0.000<0.05$ with a beta coefficient value of 0.251 . This means that religiosity has a significant positive effect on the ethical judgment. Then it can be concluded that $\mathrm{H} 2$ is accepted.

\section{The Effect of Emotional Intelligence on Ethical Judgment}

The results of the study show that Emotional Intelligence has a significant positive effect on ethical judgment. This means that the higher the student's Emotional Intelligence level, the higher the student's ethical judgment will be. Conversely, the lower the student's level of Emotional Intelligence, the lower the student's ethical judgment will be. Emotional Intelligence can influence an individual's ethical judgment when faced with an ethical dilemma. Individuals with a high level of Emotional Intelligence are sensitive to the feelings of themselves and others around them, and use this information to direct their thoughts and actions. (Salovey \& Mayer, 1990). Individuals with a high level of Emotional Intelligence believe that an action should not deceive and harm people (Angelidis \& Ibrahim, 2011). So that individuals who can 
control and manage their emotions can direct their thoughts and actions in a more ethical direction, including when making ethical judgments. Meanwhile, individuals with a low level of Emotional Intelligence tend to be willing to take actions that have a negative impact (Angelidis \& Ibrahim, 2011). Individuals with high levels of Emotional Intelligence tend to act more ethically than individuals with low levels of Emotional Intelligence (Angelidis \& Ibrahim, 2011). So that individuals who have a high level of Emotional Intelligence will direct their ethical judgment towards a more ethical one.

The results of this study also support the theory of cognitive moral development put forward by Kohlberg. The theory of cognitive moral development states that every individual experiences various stages of moral development which are influenced by the process of thinking and arguing (Kohlberg, 1969). Student moral development is at the conventional level. At this level, the individual tries to actively establish a good relationship between himself and the people around him (Nurhayati, 2006). Individuals with high levels of Emotional Intelligence tend to take actions or decisions that will benefit everyone (Angelidis \& Ibrahim, 2011). This is following the theory of cognitive moral development, individuals who have a high level of Emotional Intelligence will always take actions that do not hurt others and obey the rules of law to maintain good relations between themselves and those around them.

Judging from the results of descriptive statistical analysis, the self-emotional appraisal (SEA) indicator gets the highest total score, namely $26.64 \%$ of the four existing indicators. Individuals who can understand their emotional states tend to be better at expressing their emotions to others. This can help direct the actions and decisions of individuals as they interact with others.

The results of this study are in line with the research conducted by Ismail \& Rasheed (2019) showing that emotional intelligence positively affects ethical judgment. Research conducted on accounting students in Malaysia states that students who can understand the emotional state of those around them can direct their ethical judgment towards a more ethical one. Other studies also show the same results that Emotional Intelligence affects the ethical judgment of managers (Angelidis \& Ibrahim, 2011) and auditors (Ismail, 2015).

\section{The Effect of Religiosity on Ethical Judgment}

The results of the study show that religiosity has a significant positive effect on the ethical judgment. This means that the higher the level of student religiosity, the higher the student's ethical judgment will be. Conversely, the lower the level of student religiosity, the lower the students' ethical judgment will be and the more tolerant they are in making ethical judgments.

Religiosity affects an individual's ethical judgment in determining whether an action is ethical or unethical when facing an ethical dilemma. Religious individuals have a strong belief in God Almighty, accompanied by a commitment to apply and consider His provisions in every decision or action. (McDaniel \& Burnett, 1990). Individuals with a high level of religiosity will try to act following religious rules (Weaver \& Agle, 2002). Religiosity can influence individual actions and perceptions (Helmy, 2018). The higher the level of individual religiosity, the tighter it will be in controlling unethical behavior (Resty, 2018). So that the values of religiosity that are believed by individuals can direct their thinking about what is ethical and unethical based on the principles and commands of God Almighty. The individual will try to avoid unethical actions following the rules, orders, and provisions of God Almighty. Individuals with a high level of religiosity always obey the commands of God Almighty and always uphold ethical values. This shows that religiosity can influence individuals when making an ethical judgment.

The results of this study are also following the theory of cognitive moral development. The theory of cognitive moral development states that every individual experiences various stages of moral development which are influenced by the process of thinking and arguing (Kohlberg, 1969). The level of student moral development is at the conventional level. At the conventional level, individuals believe that an action must be carried out following the rules to avoid criticism and social disapproval (Nurhayati, 2006). Religious individuals believe and practice the values of religiosity in every consideration (Weaver \& Agle, 2002). The values of religiosity that individuals believe in the form of rules, regulations, and orders from God Almighty can influence their thinking when making ethical judgments about which actions are ethical and unethical. This is following the theory of cognitive moral development, that 
individuals with a high level of religiosity believe that they must take action following the rules they believe in, namely the rules and orders of their religion. (Weaver \& Agle, 2002).

Judging from the results of the descriptive statistical analysis, the belief dimension indicator (The Ideological Dimension) got the highest total score, namely $23.49 \%$ of the other four indicators. Based on these results, it can be concluded that the respondents showed a confident attitude towards the teachings of their religion. This means that respondents consider their religious teachings important and consider them in every action and decision they make.

This finding is in line with research conducted by Resty (2018). Research conducted on accounting students in Minangkabau states that religiosity has a positive effect on the ethical judgment. The higher the level of student religiosity, the more ethical the student will be in making a decision (Resty, 2018). The results of this study are also following the research by Walker et al., (2012) which indicates that religiosity affects ethical judgment. Individuals with a high level of religiosity will always apply religiosity values in identifying ethical and unethical behavior (Walker et al., 2012). However, the results of this study are contrary to the research by Helmy (2018) which states that there is no significant difference in ethical judgment between students who have a high or low level of religiosity.

\section{CONCLUSION}

Based on the findings in the research and discussion previously reviewed, the following conclusions can be drawn. First, Emotional Intelligence has a significant positive effect on ethical judgment among students. Students who can understand, identify and manage their emotions and others' will always direct their actions in a positive direction to maintain good relations between themselves and the people around them. So that the higher the level of Emotional Intelligence of students, the more ethical judgment will be made. Second, religiosity has a significant positive effect on ethical judgment on students. The values of religiosity that are believed by students can direct their thoughts about what is ethical and unethical based on the principles and commands of God Almighty. This also applies when students face ethical dilemma situations, so that the higher the level of student religiosity, the more assertive they will be in making ethical judgments. Thus the results of this study are expected to be used as input for educational institutions, especially at the university level, to provide services and training to accounting students to improve their Emotional Intelligence and religiosity. Besides, companies can also add indicators of Emotional Intelligence and religiosity in recruiting accounting staff and corporate auditors. This can be done as a step to maintain and increase the company's credibility and integrity in the future.

The limitation of this study is that the subjects used in this study are accounting students who still have no experience in the world of work. So there is the possibility that these findings will differ from their actions and decisions when they are faced with ethical dilemma situations in the work environment later. Future studies should use accountants or auditors who have experience in the work environment as research subjects. Further research can also add other relevant factors, both internal and external, that influence ethical judgment such as age, gender, moral reasoning, ethical education, ethical climate, and organizational ethical culture.

\section{REFERENCES}

Akers, M. D., \& Porter, G. L. (2003). Your EQ Skills: Got What It Takes? Journal of Accountancy, 195(3), 65-70.

Angelidis, J., \& Ibrahim, N. A. (2011). The Impact of Emotional Intelligence on the Ethical Judgment of Managers. Journal of Business Ethics, 99(1), 111-119. https://doi.org/10.1007/s10551-011-1158-5

Aziz, A., \& Cahyonowati, N. (2015). Pengaruh Ethical Ideology Terhadap Ethical Judgements Pada Mahasiswa Akuntansi. Diponegoro Journal of Accounting, 4(3), 437-444.

Chan, S. Y. S., \& Leung, P. (2006). The Effects of Accounting Students' Ethical Reasoning and Personal Factors on Their Ethical Sensitivity. Managerial Auditing Journal, 21(4), 436-457. 
https://doi.org/10.1108/02686900610661432

Deshpande, S. P., \& Joseph, J. (2009). Impact of Emotional Intelligence, Ethical Climate, and Behavior of Peers on Ethical Behavior of Nurses. Journal of Business Ethics, 85(3), 403-410. https://doi.org/10.1007/s10551-008-9779-Z

Dewi, P. E. D. M., Martadinata, I. P. H., \& Diputra, I. B. R. P. (2019). Analisis Hubungan Kecerdasan Emosional Dan Love of Money Terhadap Perilaku Etis Mahasiswa (Studi Empiris Pada Mahasiswa S1 Akuntansi Universitas Pendidikan Ganesha). Jurnal Ilmiah Akuntansi. 3(2), 154-170. https://doi.org/10.23887/jia.v3i2.16638

Economica. (2019). PwC Italy Partner Named in BT Criminal Investigation. (Online), (https://economia.icaew.com/news/february-2019/pwc-italy-partner-named-in-bt-criminalinvestigation), accessed on 4 November 2019

Emerson, T. L. N., Conroy, S. J., \& Stanley, C. W. (2007). Ethical attitudes of accountants: Recent evidence from a practitioners' survey. Journal of Business Ethics, 71(1), 73-87. https://doi.org/10.1007/s10551-006-9125-2

Fadhilah, A. N. (2019). Analisis Pengaruh Kompetensi Moral, Tingkat Religiusitas, dan Efikasi Diri Terhadap Academic Dishonesty. Unpublished Undergraduate Thesis. Malang: Faculty of Economics and Business, Universitas Negeri Malang

Helmy, H. (2018). The Influence of Ethical Orientation, Gender, and Religiosity on Ethical Judgment Accounting Students. Advances in Economics, Business and Management Research, 57, 50-56. https://doi.org/10.2991/piceeba-18.2018.78

Hunt, S. D., \& Vitell, S. (1986). A General Theory of Marketing Ethics. Journal of Macromarketing, 6, 516.

Ismail, S. (2015). Influence of Emotional Intelligence, Ethical Climates, and Corporate Ethical Values on Ethical Judgment of Malaysian Auditors. Asian Journal of Business Ethics, 4(2), 147-162. https://doi.org/10.1007/s13520-015-0047-x

Ismail, S., \& Rasheed, Z. (2019). Influence of Ethical Ideology and Emotional Intelligence on The Ethical Judgement of Future Accountants in Malaysia. Meditari Accountancy Research. https://doi.org/10.1108/medar-04-2018-0326

Jaafar, J., Kolodinsky, P., McCarthy, S., \& Schroder, V. (2004). The impact of cultural norms and values of the moral judgment of Malay and American adolescents: A brief report. Papers from the International Association for Cross-Cultural Psychology Conference, 399-414.

Keller, A. C., Smith, K. T., \& Smith, L. M. (2007). Do Gender, Educational Level, Religiosity, and Work Experience Affect The Ethical Decision-Making of U.S. Accountants? Critical Perspectives on Accounting, 18(3), 299-314. https://doi.org/10.1016/j.cpa.2006.01.006

Kohlberg, L. (1969). Stage And Squence: The Cognitive-Developmental Approach To Socialization. 347480.

Kohlberg, L. (1984). Essays on moral development: The psychology of moral development (Vol. 2). New York: Harper \& Row

McDaniel, S. W., \& Burnett, J. J. (1990). Consumer Religiosity and Retail Store Evaluative Criteria. Journal of the Academy of Marketing Science, 18(2), 101-112. https://doi.org/10.1007/BF02726426

Mesmer-Magnus, J., Viswesvaran, C., Joseph, J., \& Deshpande, S. P. (2008). The Role of Emotional Intelligence In Integrity and Ethics Perceptions. Research on Emotion in Organizations, 4(8), 225239. https://doi.org/10.1016/S1746-9791(08)04010-8 
Nasikhah, D., \& Prihastuti. (2013). Hubungan antara Tingkat Religiusitas dengan Perilaku Kenakalan Remaja pada Masa Remaja Awal . Jurnal Psikologi Pendidikan Dan Perkembangan], 2(2), 69-72.

Nurhayati, S. (2006). Telaah Kritis Terhadap Teori Perkembangan Moral Lawrence Kohlberg Paradigma: Jurnal Psikologi Pendidikan Dan Konseling, (2), 93-104.

Pamungkas, I. D. (2014). Pengaruh Religiusitas dan Rasionalisasi dalam Mencegah dan Mendeteksi Kecenderungan Kecurangan Akuntansi. Jurnal Ekonomi Dan Bisnis. 15(2), 48-59.

Rahmawati, A. (2019). Pengaruh Fraud Diamond, Reigiusitas, dan Self Efficacy Terhadap Academic Fraud

Resty, N. N. H. (2018). Pengaruh Religiusitas dan Gender Terhadap Penilaian Etis (Ethical Judgement) Mahasiswa Akuntansi Minangkabau. Jurnal EcoGen.1(4), 858-869.

Reuters. (2019). Exclusive: BT Executives Knew of Accounting Fraud in Italy Unit - Prosecutors. (Online). (https://www.reuters.com/article/us-bt-italy-exclusive/exclusive-bt-executives-knew-ofaccounting-fraud-in-italy-unit-prosecutors-idUSKCN1Q216M), accessed 4 November 2019

Sagoro, E. M. (2013). Pensinergian Mahasiswa, Dosen, dan Lembaga Dalam Pencegahan Kecurangan Akademik Mahasiswa Akuntansi. Jurnal Pendidikan Akuntansi Indonesia, 11(2), 54-67. https://doi.org/10.21831/jpai.v11i2.1691

Salovey, P., \& Mayer, J. D. (1990). Emotional Intelligence. Imagination, Cognition and Personality, 9(3), 185-211. https://doi.org/10.2190/DUGG-P24E-52WK-6CDG

Suliani, M., \& Marsono. (2010). Pengaruh Pertimbangan Etis, Perilaku Machiavelian, dan Gender dalam Pembuatan Keputusan Etis Mahasiswa S1 Akuntansi Jurnal Akuntansi Dan Auditing. 7(1), 62-79. https://doi.org/10.14710/jaa.v7i1.4677

Walker, A. G., Smither, J. W., \& DeBode, J. (2012). The Effects of Religiosity on Ethical Judgments. Journal of Business Ethics, 106(4), 437-452. https://doi.org/10.1007/s10551-011-1009-4

Weaver, G. R., \& Agle, B. R. (2002). Religiosity and Ethical Behavior in Organizations: A Symbolic Interactionist Perspective. Academy of Management Review, 27(1), 77-97. https://doi.org/10.5465/AMR.2002.5922390

Wong, C., \& Law, K. S. (2002). The Effects of Leader and Follower Emotional Intelligence on Performance and Attitude : An Exploratory Study. The Leadership Quarterly, 13, 243-274. 